\title{
Same menu, seperate tables: The institutionalist turn in political science and the study of European integration
}

\author{
MARK D. ASPINWALL ${ }^{1} \&$ GERALD SCHNEIDER ${ }^{2}$ \\ ${ }^{1}$ University of Durham, UK; ${ }^{2}$ University of Konstanz, Germany
}

\begin{abstract}
Recent research on European integration has largely profited from the institutionalist turn in political science. Theoretical progress has, however, been hampered by the diverse understandings of this new research tradition. This paper tries to tackle the conceptual diversity in a positive way. We first analyze the neo-institutionalist turn in political science and European studies and then move on to a detailed analysis and comparison of the three competing approaches - sociological, historical, and rational choice institutionalism. Next, we will show that the main differences are as much epistemological as theoretical. A convergence towards a unifying institutionalist approach can thus only be possible if some sort of a methodological convergence takes place. We sketch how a synthesis between the competing schools might appear.
\end{abstract}

'In my country there is a belief ... that the only thing separating us from the animals is mindless superstitions and pointless rituals'.

Quoted from Latka, 'Taxi', in Tad Tuleja Curious Customs (New York: Harmony Books), p. xii.

'Love and War are the same thing, and strategems and policy are as allowable in one as in the other'.

Miguel de Cervantes, Don Quixote (reprint, New York: Modern Library, 1955, p. 580, quoted in Tim O'Brien 1995. In the Lake of Woods. New York: Penguin, p. 193.)

\section{We are all institutionalists now}

A few years ago, the distinguished comparativist Gabriel A. Almond (1990) complained about the state of the art in political science. His main assertion was that epistemological and ideological differences prevent scholars from engaging in a productive discussion beyond small sects of like-minded people. We can now observe a similar development in studies on European integration. Although ideological conflicts have waned even in academia and although the distinction between 'quantitative' and 'qualitative' research seems increasingly obsolete (King, Keohane \& Verba 1994), sharp divi-

Konstanzer Online-Publikations-System (KOPS)

URL: http://www.ub.uni-konstanz.de/kops/volltexte/2008/7130/

URN: http://nbn-resolving.de/urn:nbn:de:bsz:352-opus-71301 
sions still characterize the theoretical debate on regional collaboration. The protraction of these disputes is all the more paradoxical since the contending approaches share, at least at first sight, some common ground. The most important sign of theoretical convergence is, of course, that almost any Europeanist with a minimal level of self-respect flags herself as an 'institutionalist' at the moment.

The institutionalist turn in integration studies dates back at least to Scharpf's seminal articles $(1985,1988)$ on the joint-decision trap. His lament that traditional approaches such as neofunctionalism have largely ignored the impact of decisionmaking rules on the integration process coincided with the publication of March \& Olsen's (1984) pioneering piece which heralded the institutionalist turn in political science. In the meantime, institutionalist analysis has been turned into the mainstream approach in political science. Even though integration studies have always been rather slow in adapting to conceptual changes, they too were finally reached by the disciplinary change of tide. Since the early 1990s we have witnessed a proliferation of studies on the relative power of institutional actors, examinations of the complexities of bargaining between actors from different levels, and evaluations of the role that norms and socialization play in the process of European integration.

Despite these impressive achievements almost no convergence towards a common understanding of European institutions has occurred. On the contrary, a considerable promiscuity characterizes the way in which researchers deal with different facets of rule-based behavior. This partly reflects the state of the art in the general discussion where no consensus definition of institutions and their salient attributes has been reached. The conceptual indeterminacy matters more, however, in the relatively volatile field of European studies where only a gradual turn towards theoretically innovative and empirically systematic research designs can be observed. Instead of offering insights to other subdisciplines, integration research is still heavily dependent upon imports from other disciplines.

We argue that epistemological rather than theoretical differences constitute some of the most important divisions between the contending approaches. This means that Europeanists assume to sit in different restaurants and, more importantly, employ different utensils to attack what we consider to be the same menu. While most sociological and historical institutionalism is inductively searching for the patterns of European collaboration, rational choice theorists aim at uncovering the rules of regional integration in a deductive fashion. If they do not shy away from a systematic testing of their theories, their empirical strategy often consists of quantitative evaluations of basic propositions. The research design of the sociological and historical 
institutional approaches, conversely, is often (but not always) limited to a case study framework.

In addition, important ontological differences separate the institutionalist traditions, and these are perhaps less reconcilable. To carry the metaphor a little further, some Europeanists like to separate grappa and coffee, while their counterparts prefer the Italian way of mixing them up. The fundamental sources of human behavior from the rationalist perspective come from outside the agent and her context. From the sociological and, to an extent, the historical perspective, the agent and her context are co-determining; they evolve simultaneously, and do not exist independently. These different ontologies can, however, co-exist on the same menu because the restaurant's etiquette only insists upon a scientific approach from all diners. We explore these differences in more detail below.

This article tries to live up to the daunting task of exploring these differences and of finding some common ground between the different institutionalisms. Neo-institutionalism is usually divided into two major variants - rational choice and historical (Bulmer 1994; Shepsle 1989; Moe 1991; Norgaard 1996). However, we adopt the distinction by Hall \& Taylor (1996) of three institutionalisms - sociological, historical, and rationalist. ${ }^{1}$ The reason is that there are important differences between the historical and sociological approaches which we try to draw out and clarify in this paper. In addition, there are important areas of agreement between all three approaches, so that it is perhaps more appropriate to think of them not as discrete conceptual categories but as points along a continuum, or as independent nodes with areas of commonality.

The article is structured as follows: We first present a review of the contending approaches and then move on to an evaluation of the most important institutionalist research in European studies. The final section demonstrates the potential for convergence.

\section{An overview of the three contending approaches}

The basic premise of neo-institutionalist analysis is that institutions affect outcomes. Institutions contain the bias individual agents have built into their society over time, which in turn leads to important distributional consequences. They structure political actions and outcomes, rather than simply mirroring social activity and rational competition among disaggregated units (March \& Olsen 1984; 1989; Thelen \& Steinmo 1992; Lindberg \& Campbell 1991).

This key postulate leaves a great many questions in its wake, however, and one problem of the institutionalist turn in political science is the am- 
biguity that characterizes the whole research program. Hans Keman (1997: 1) comes to a similar conclusion when he writes: "new institutionalism is ... characterized by a clear lack of conceptualization of what institutions are, or how they can be defined'.

Rationalists on the one hand see institutions mainly as 'long-lived equilibrium patterns of rational behavior' and thus realized outcomes in a strategic game 'that society plays' (Calvert 1994: 218). At the other extreme, institutions constitute human identity and behavior. From this perspective, 'all problems are common; all solutions socially constructed and reified; all expectations common and publicly hegemonic' (Berger \& Luckmann, cited in Jepperson 1991: 151). This sociological view often assumes that institutions have cultural roots and in fact sees culture and institutions as somewhat synonymous. In a review of the literature, Finnemore (1996: 333) states that 'the institutionalists' structure is a cultural one; it is Western rationality and individuality that creates states, markets, bureaucratic organizations'. The competing definitions owe much to the legacies of Max Weber and Emile Durkheim. In the former perspective, institutions shape behavior, but ultimately they do not determine it. Durkheimian sociologists, conversely, attribute the overriding influence to social structure. Although the new institutionalisms link the two theoretical strands, sociological institutionalism is much more influenced by the Durkheimian research tradition than is rational choice.

These are two ends of the same spectrum, which varies according to the extent to which institutions are internalized by agents and therefore the extent to which they are susceptible to conscious manipulation. Moreover, the field is characterized by pluralism not simply in what institutions are assumed to do, but also in the definitions of institutions: Peter Hall (1986: 19), for example, defines institutions as 'the formal rules, compliance procedures, and standard operating practices that structure the relationship between individuals in various units of the polity and economy', Much broader, but still quite commonsensical is Asbjorn Norgaard's (1996: 39) recent statement that they are 'legal arrangements, routines, procedures, conventions, norms, and organizational forms that shape and inform human interaction.'

This article is based on the understanding that institutions encompass both formal and informal structures that influence human behavior. In the European Union, voting or legislative procedures are in the former category. The Council's drive towards consensus solutions even in the event that qualified majority decisions are possible is an example of an important informal rule. Cultural practices and cognitive patterns also fall into this category.

The effects of institutions on human action can be either constraining or empowering. One side of this dual role is accordingly that rules prevent 
actions that might otherwise be pursued. National constitutions or deeply entrenched social traditions might for instance hinder the development of lasting transnational relations in the European arena. The other facet of rulebased behavior is that institutions such as equal voting power enable actors to undertake certain actions that might seem inconceivable in other circumstances. For instance, to promote gender equality in reluctant member states, the European Court of Justice referred to Article 119 of the Treaty of Rome which obliges the introduction of measures guaranteeing 'equal pay for equal work' (Pierson 1996). Moreover, shared cultural and cognitive-based understandings may promote common action, whereas different understandings may act as a constraint.

In the context of European collaboration, institutions can function as independent, intervening or outcome variables. As independent variables, they include bedrock values, ideas, and norms at the national, organizational, or some other level. As intervening variables, they may comprise codified, clearly-visible rules or they may be routines and standard practices which are less visible but equally important determinants of social behavior. As dependent variables, they include those equilibria and patterns of behavior that characterize the process of European collaboration.

Since rules affect behavior at all levels of societal interaction, neoinstitutionalism has no theoretical bias towards either 'high' or 'low' politics or towards either vertical or horizontal forms of cooperation. In the reform of the Structural Funds, institutions such as the division of power between federal and regional actors or the dominant bargaining principles have for instance proven to be important in the administration of funds (Payne, Mokken \& Stokman 1997). The checks and balances that have been established for the interactions between the European Commission, the Council of Ministers, the Court of Justice and the European Parliament consists of a myriad of sometimes rather byzantine rules (Moser \& Schneider 1997).

As we suggested earlier, there may be considerable convergence between the 'new institutionalisms' in certain respects. For example, some historical institutionalists share with rational choice institutionalists an emphasis on actor intentionality in the short term (Pierson 1996). Other historical institutionalists tend to emphasize the long-term consequences of institutions particularly their tendency to influence preferences (Bulmer, 1994) - and thus share with sociological institutionalists a preoccupation with endogenized behavior.

Nonetheless, no synthesizing approach is in sight. One of the most important underlying differences between theorists concerns the time horizon. Rational choice theorists tend to concentrate on short-term decisionmaking. Sociological institutionalists concentrate on long-term institutional effects. 
Likewise, historical institutionalists concentrate on the long term effects of specific (possibly rational) decisions. Closely related to this (and indeed probably co-varying with temporal differences) is the extent to which institutional effects are 'internalized' by agents. From the rational choice perspective, institutions are most often external to the agent - including voting procedures and conflict resolution mechanisms - unless actors are engaged in the conscious creation of rules. One basic distinction in the rationalist literature is accordingly between games on rules and games within rules. From the sociological perspective institutions are internalized - including identitive institutions such as nationality or religion. It follows that these different emphases will cause observers to stress alternative explanations for the logic of action, the interpretation of rules, and the formation of preferences and strategies.

The differences between the contending approaches become more obvious if we analyze them in detail. Table 1 shows accordingly that all approaches understand institutions as rules and norms. ${ }^{2}$ Our standards of assessment fall basically into three categories. We first distinguish between the approaches of the different institutionalist schools of thought, particularly with reference to their scientific world-view; we then move on to their understanding of institutions and the time frame which characterizes the typical research designs. Finally, we highlight the ways in which the approaches deal with three general problems: preference formation, the creation of institutions, and their evolution. We illustrate the differences with examples from recent research.

\section{Historical/sociological institutionalism}

Theorists clearly distinguish historical and sociological institutionalism from rational choice institutionalism (compare Norgaard 1996 and Moe 1991 to Thelen \& Steinmo 1992). Although there are significant differences between them, they both accord institutions an important independent role, and view humans as rooted in particular contexts; their menu of options and preferences is limited by the repeated historical practice of interaction and by the social setting in which they find themselves.

From both historical and sociological perspectives institutions provide an environment in which political struggles are played out and which structure the game by providing a set of rules. In fact, there is common ground with the rational choice institutionalism in the most basic assumption, namely that institutions influence individual action. Historical and sociological institutionalism sees institutions as providing a political environment or cultural context which alters the individual's sense of what is in her best interests in other words, actors are conditioned by the accumulation of procedures, rules, and norms over time. Identities, priorities, interpretations of reality are 
Table 1. Main features of the three institutionalist approaches

\begin{tabular}{|c|c|c|c|}
\hline & $\begin{array}{l}\text { Sociological } \\
\text { institutionalism }\end{array}$ & $\begin{array}{l}\text { Historical } \\
\text { institutionalism }\end{array}$ & $\begin{array}{l}\text { Rationalist } \\
\text { institutionalism }\end{array}$ \\
\hline Scientific world view & $\begin{array}{l}\text { Holism, } \\
\text { constructivism; } \\
\text { group identity; } \\
\text { shared past/common } \\
\text { experience }\end{array}$ & $\begin{array}{l}\text { Modified egoism; } \\
\text { agency constrained } \\
\text { or structured by } \\
\text { common agreement }\end{array}$ & $\begin{array}{l}\text { Methodological } \\
\text { individualism; } \\
\text { optimizing and } \\
\text { strategic behavior }\end{array}$ \\
\hline $\begin{array}{l}\text { Typical research } \\
\text { design }\end{array}$ & $\begin{array}{l}\text { Case studies of } \\
\text { cultural, cognitive } \\
\text { links. }\end{array}$ & $\begin{array}{l}\text { Historical sociology, } \\
\text { case studies }\end{array}$ & $\begin{array}{l}\text { Casual illustrations } \\
\text { of hypotheses, } \\
\text { macroquantitative } \\
\text { tests }\end{array}$ \\
\hline Time horizon & Long term & Long term & Short term \\
\hline $\begin{array}{l}\text { Definition of } \\
\text { institutions }\end{array}$ & Norms, rules, culture & $\begin{array}{l}\text { Informal and formal } \\
\text { rules }\end{array}$ & Rules, procedures \\
\hline $\begin{array}{l}\text { Role of institutions } \\
\text { for human action }\end{array}$ & $\begin{array}{l}\text { Major independent } \\
\text { variable; cultural } \\
\text { constraint. }\end{array}$ & $\begin{array}{l}\text { Intervening variable. } \\
\text { Grown constraint } \\
\text { and opportunity }\end{array}$ & $\begin{array}{l}\text { Intervening variable. } \\
\text { Situative constraint } \\
\text { and opportunity }\end{array}$ \\
\hline Preference formation & $\begin{array}{l}\text { Constitution of } \\
\text { actors through } \\
\text { institutions; } \\
\text { endogeneous process }\end{array}$ & $\begin{array}{l}\text { Endogenous. } \\
\text { Creation of } \\
\text { institutions affects } \\
\text { preferences. }\end{array}$ & $\begin{array}{l}\text { Exogeneous to the } \\
\text { model or decision- } \\
\text { theoretic explanation }\end{array}$ \\
\hline $\begin{array}{l}\text { Creation of } \\
\text { institutions }\end{array}$ & $\begin{array}{l}\text { Evolutionary; } \\
\text { occasional abrupt } \\
\text { changes caused by } \\
\text { new events or } \\
\text { reinterpretations. }\end{array}$ & $\begin{array}{l}\text { Delegation; self- } \\
\text { maintaining and } \\
\text { potentially expansive }\end{array}$ & $\begin{array}{l}\text { Distributional } \\
\text { conflict, reduction of } \\
\text { transaction costs or } \\
\text { collective dilemma } \\
\text { as driving force }\end{array}$ \\
\hline $\begin{array}{l}\text { Evolution of } \\
\text { institutions }\end{array}$ & $\begin{array}{l}\text { Cognitive/memory - } \\
\text { process of } \\
\text { mythologizing } \\
\text { common events. }\end{array}$ & $\begin{array}{l}\text { Contingent processes } \\
\text { with path } \\
\text { dependency and } \\
\text { unintended } \\
\text { consequences }\end{array}$ & $\begin{array}{l}\text { Bargaining process, } \\
\text { evolutionary } \\
\text { selection }\end{array}$ \\
\hline
\end{tabular}

all created by this context. In contrast to the rationalist, to whom institutions represent a strategic operating environment, actors have less ability to set priorities independent of the institutional context. In this view, human action is more context-driven than goal-driven. 
In sociological institutionalism and certain aspects of historical institutionalism, agents form preferences endogenously, and these are to a certain extent 'path dependent'. Over time contexts may change, but since humans are social animals their preferences and priorities change with them. A further point of convergence is the scientific orientation of the two approaches, both of which tend to be holistic. One consequence of this outlook is that the typical research design of the two approaches is largely influenced by historical sociology and other related approaches.

However, important differences exist between the historical and sociological approaches as well: both Hall \& Taylor (1996) and Finnemore (1996) distinguish between the structural and constraining features of historical institutionalism and the cognitive and culturally embedded features of sociological institutionalism. As Thelen \& Steinmo (1992: 8) put it, historical institutionalists argue that 'not just the strategies but also the goals actors pursue are shaped by the institutional context'. They move beyond the institution as a strategic environment within which actors pursue exogenously-given interests, and define institutions as having a much more important role in shaping political inputs as well as outcomes. The state is the most relevant institutional environment here. '[T] he state is not only affected by society but also affects it ... processes internal to political institutions, although possibly triggered by external events, affect the flow of history' (March \& Olsen 1989: 17-18; also, Skocpol 1985).

It is also possible to distinguish between historical institutionalists, namely those whose research proceeds from an essentially rationalist perspective (but concentrates on the 'unintended consequences' of rational decisions (Pierson 1996; Immergut 1992); and those whose work concentrates more on the long term consequences of institutions for actors' preferences and strategies (Armstrong and Bulmer 1997). Much of the basis for these different approaches is the extent to which institutional norms and constraints have been assimilated by actors. To those in the former tradition, actors are still adjusting to the obstacles in their path. To those in the latter tradition, actors have internalized these institutional constraints.

From the sociological perspective, culture is extremely important because it contains the bedrock cognitive similarities that cause people to share perceptions of the world around them (Campbell et al. 1991). Although theorists also denote formal organization and regimes as 'carriers of institutionalization' (Jepperson 1991: 150), culture is one of the most important driving forces behind the institutionalization of human behavior. Legitimacy is also a crucial concept in sociological institutionalism, because it helps to explain similarities in organizational forms across spaces and in places where 
functional demands had not warranted them. Pursuit of legitimacy leads to patterned behavior.

Therefore, sociological institutionalism perceives institutions as major independent variables. This becomes obvious in a statement by DiMaggio and Powell (1991: 11): 'Institutions do not just constrain options; they establish the very criteria by which people discover their preferences'. Institutions are constitutive, in that they comprise the criteria by which agents form their identity. They develop a 'corresponding canopy of legitimations, stretching over it a protective cover of both cognitive and normative interpretation' (Berger and Luckmann, 1967: 79). Thus, agents do not bounce between institutions as they venture from one objective to another; agent and structure are inextricably bound together - the actions of agents are impossible to comprehend without reference to the cognitive, culturally-informed 'institutions' within which they exist. Culture and institutions therefore become virtually synonymous under the sociological rubric. Unlike historical or rational choice institutionalism there is no conception of institutional choice.

The relationship between agency and structure was taken a step further by Giddens $(1984,1976)$, who theorized the mutually constitutive effects of agency and structure and who viewed structural rules, defined by him as internal to the actor, as both enabling and constraining (on structuration in international relations, see Ruggie 1998). In his structuration approach agents produce structure, in that they creatively employ social skills in everyday situations, and also reproduce structure, thus enabling it to endure beyond any individual's lifetime. Structuration is important as a potential means of bridging the gap between rational choice and constructivist approaches since it recognises both the influence of agency and also the influence of structure. In order to accomplish this, however, the deeply embedded social practices which comprise structure must themselves become the object of analysis.

Culturally-based commonalities do not erase the potential for conflict far from it. But common interpretations of events, made possible by shared cultural norms or some habitualized practice, reduce transaction costs and lead to what Berger \& Luckmann term an 'economy of effort' (1967: 71). These boundaries may occur at the national, subnational, or organizational level. Conversely, actors with similar interests who do not emerge from the same cultural context find that there is a cross-cutting cleavage separating them. This has occurred repeatedly in efforts to agree to common economic policies in the EU - actors from some states or sectors consistently prefer a liberal approach; actors from other states or sectors a protectionist approach. The differences may be traced not simply to transient interests, but to longerterm divergence in normative conceptions of capitalism. 
To summarize, it is possible to distinguish between institutional structures that are more explicit, intentional and recognised on the one hand; and cultural features that are implicit, internalized, and potentially unrecognized on the other. However, these approaches to institutions are not without their critics. Koelbe (1995: 239), for example, criticizes the feedback conceptualization of institutions and states: 'Individuals are not helpless when it comes to institutional choice, but historical institutionalists insist that institutions guide their choices. In the end, it is unclear whether the intentions of individuals or the constraints imposed by institutions shape outcomes'. In historical institutionalism, structure may indeed be created by agents; but subsequently, like Frankenstein's monster, structure takes on a life of its own.

Moreover, it is very difficult to measure the effect of culturally-derived institutions, because it is virtually impossible to surmise, except by counterfactuals, what the event would have produced in the absence of these institutions. Control groups do not exist. According to the very paradigm, it is impossible to imagine individuals acting without reference to cultural roots; to ascertain the effects of these roots becomes exceedingly difficult. Finally, it is somewhat problematic to make a clear differentiation in practice between the effects of culture and cognition and the effects of structure and constraint.

\section{Rational choice institutionalism}

The rational choice version of institutionalism is not as coherent a research program as is often thought. The most important differences are over the creation and maintenance of rules where bargaining (Knight 1992) or evolutionary selection (Axelrod 1984; Arthur 1994) become increasingly recognized as the most important driving forces. This is also the case for those transaction costs economists who originally saw political institutions as the more or less automatic result of externality and public goods problems (North 1981; Williamson 1985).

Obviously, almost all adherents of this approach agree with the precepts of methodological individualism. Accordingly, human action is considered to be the cornerstone of any social scientific explanation. The rational choice perspective originally derives from neo-classical economics and views humans as utility-maximizers who are able to rank their priorities in accordance with fixed, exogenous preference scales. This paradigm stresses individual motivation through material gain, and even if theorists do not reject the social qualities of human agents (Buchanan 1979), actors are conceived as more independent of context.

During the past two decades, most rational choice work has been largely influenced by non-cooperative game theory. This approach generally studies 
how individuals make decisions if they know that the ultimate outcome is also influenced by other actors. If rational choice approaches do not fall into the trap of functionalist analysis and conceive of institutions as the answers to some societal 'need', they pay attention to the potential for inefficient responses. Second- or even third-best responses often flow from the gap that lies between social and individual rationality. In general, rational choice institutionalism sees politics as an arena in which individuals try to maximize their personal gain. Since most decisions are affected by several individuals, decision making has to be seen as an interdependent process. Since actors might have incentives to cheat on other players, a society might end up with institutions that are suboptimal from a collective viewpoint. The Prisoners' Dilemma and other socially problematic game situations such as the Centipede or the Chicken Game are some of the famous metaphors with which rational choice researchers have analyzed the tension between individual and social interests.

The rational choice approach has first and comfortably found its way into international relations, where it assumes that actors behave in a strategic manner, adapting their strategies and beliefs to the assumed actions of other players. States desiring gains from cooperation, therefore, create and maintain institutions to lower the transaction costs associated with inter-state activity, such as incomplete contracting, imperfect information, and the inability to monitor and enforce agreements. Cooperation, therefore, is instrumental, and is not necessarily a socially-ingrained and habitual practice.

Rational choice institutionalism consequently sees institutions as providing a context within which individual decisions are set, but places the emphasis on 'individual' rather than 'context'. They are, to quote Shepsle (1989: 135), 'equilibrium theories. They seek to explain characteristics of social outcomes on the basis not only of agent preferences and optimizing behavior, but also on the basis of institutional features'. Institutions provide a set of formal rules and procedures, or informal practices, that structure relationships. North (1981: 12) voiced this when he said that 'something more than an individualistic calculus of cost/benefit is needed in order to account for change and stability'. Institutions were the missing element in neoclassical economics. They 'provide the framework within which human beings interact. They establish the cooperative and competitive relationships which constitute a society ...' (North, 1981: 201).

Rational choice theorists generally start from preferences that are exogeneous to their model. This general assumption is made because one element has to be fixed in order to reach explanatory power. If a model allows every variable to change, nothing can be explained. Preference change can thus only be modeled if other factors are held constant. This is the analytic trick 
behind Becker's (1996) decision-theoretic extension of the basic economic model with which he can rigorously account for socialization and addiction. Becker's model, however, has not yet been applied to institutional and strategic questions. ${ }^{3}$

Rational choice generally uses, in comparison with the other approaches, a more narrow definition of institutions. In the rationalist approach to European integration, institutions are formal and informal rules that regulate and shape human interactions. Although no rationalist work on the impact of organizational culture has been undertaken, such applications are theoretically feasible. This at least suggests the early contribution by Kreps (1990; originally published in Japanese in 1984) who delineated the strategic role of trust and other social norms. Rational choice reasoning also lends itself to the analysis of how inefficient conventions and norms are selected and maintained. David's (1985; see also Arthur 1994) analysis of the impractical QWERTY keyboard standard is the classic example that institutionalist reasoning has no inherent bias in favor of either optimal or second-best solutions.

One important aspect of rational choice reasoning in contrast to the more extreme versions of sociological institutionalism is that it does not assume that institutions precede human action. In accordance with historical institutionalists, rationalists perceive institutions mainly as an intervening rather than an independent variable. However, we do not think that these differences should necessarily impinge on the way in which institutionalist research is carried out. The close comparison shows that the main differences are the basic goals and scientific orientations that separate the three research traditions. Historical and sociological institutionalism aim at 'thick' description, at least in the field of European studies, though large quantitative studies of the emergence of a homogenous world culture have also been undertaken. On the other hand, rational choice approaches have an inbuilt bias towards parsimonious explanation.

The other differences between the approaches are a consequence of this basic epistemological division. For instance, divergent opinions on the feasibility and desirability of endogenizing preference change are not one of the major reasons why a theoretical convergence between the competing institutionalisms seems unlikely. It is simply an effect of profoundly different research designs. Historical and sociological institutionalist typically describe how such changes take place. Rationalists, by contrast, put much higher emphasis on the establishment of a causal mechanism under which an endogenous change of taste becomes more likely. If they cannot come up with a convincing model, the topic disappears from their research agenda.

All methodological approaches have distinct advantages and disadvantages. The empirical/descriptive approaches are highly detailed, but tend not to 
yield a discernible pattern upon which generalizations can be made, not least because of the widespread habit to examine one case at a time. The deductive modeling approaches are more explicit in their a priori expectations, but do not always offer unambiguous and generalizable empirical support. Many of these divergences are based on one fundamental ontological difference: rational choice and certain historical institutionalists believe in the human as a distinct, survival-conscious unit; sociological and some historical theorists start from the holistic premise that humans are part of a whole and that they do not exist in a meaningful way outside that whole. We will discuss shortly how the basic differences become apparent in the theoretically guided research on European integration.

\section{Diverging views on institutionalism and European integration}

Like the new institutionalism as a whole, there is no consensus on how to think about the role of institutions in European integration. To illustrate this diversity of views, we review some of the extant work in the field.

\section{Rational choice}

Rational choice research on the European Union builds on the noncooperative assumption that actors in all relevant decision making arenas behave strategically to reach their preferred outcome. ${ }^{4}$ Since the European Union has gradually evolved into a complex power sharing system, most interactions are affected by the way power is delegated from principals to agents (Moser \& Schneider 1997). Typical principals are voters who yield treaty making power to their governments. Political executives are, conversely, principals in their own right on whose orders supranational institutions act. Delegating power is not trivial since agents often pursue their own goals, profiting from their superior knowledge and experience. Rational choice theorists have focused to a considerable extent on how agents exploit the uncertainty stemming from the imperfect division of power between competing European actors.

Most research has been particularly influenced by signaling games and the spatial theory of voting. ${ }^{5}$ As is the case with other subfields, substantial progress has mainly come from those scholars who actively engage in the task of building their own models. Game theoretical concepts have, however, also been a major source for the metaphorical analysis of the European Union. 'Consumers' of rational choice do, however, most often content themselves with the import of some idea without developing them further (Schneider 1994). ${ }^{6}$ In other words, 'soft' applications of the rationalist paradigm often 
suffer under the problem of coming up with hypotheses that seem plausible, but cannot be traced back to a convincing deductive framework.

Theoretical advances have first and foremost been made in the analysis of the ways in which institutional reforms such as the introduction of the Single European Act or the Treaty on European Union have redistributed decision making power among the competing actors. According to Steunenberg (1994, similarly Crombez 1996), the introduction of the cooperation procedure and the codecision procedure did not diminish the influence of the European Commission in comparison with the European Parliament. This view is partly challenged by Moser $(1997 \mathrm{a}, \mathrm{b})$ who contends that codecision can force the Commission to accept proposals by the European Parliament which deviate from its own preference. In his evaluation of Tsebelis's study on the Parliament's alleged conditional agenda setting power (1994/5), Moser shows that the legislature can only exert an independent effect under the cooperation procedure if the decision making context changes over time. Under the codecision procedure, by contrast, the European Parliament has obtained for the first time unconditional veto power (Schneider 1995). This gradual strengthening will continue under the new codecision procedures since the Council now definitively lost the possibility of returning to its initial proposal after a failed compromise (Steunenberg 1998, see also Crombez 2000 and Tsebelis \& Garrett 2000).

The introduction of rules on the implementation of EU measures (the socalled 'comitology' procedures) has led, by contrast, to a strengthening of the intergovernmentalist rather than the supranationalist actors. As Steunenberg, Koboldt \& Schmidtchen $(1996,1997)$ demonstrate, the Council has obtained considerable 'gatekeeping' power on some supranational proposals. Franchino (2000) demonstrates in a macro-quantitative study that strategic considerations are highly important in this context. Another institution within the European Union that has been studied by rationalists is the European Court of Justice. Garrett (1992) offered a first strategic interpretation of ECJ decision making. He conjectured that '.. the actions of all courts are fundamentally political in that they anticipate the possible reactions of other political actors in order to avoid their interpretation'. Although he qualified this interpretation, Garrett (1995) used an exchange with Mattli \& Slaughter (1995) to reiterate that the ECJ behaves in a strategic fashion and systematically takes the possible reactions of the member states into account. Alter (1998) as well as Mattli \& Slaughter seem to agree with this.

The first generation of spatial models on decisionmaking in the European Union has been largely devoted to the actors' objective influence, without systematically analyzing the very individual ways in which actors make use of different institutional settings. In our view, this narrow focus is problematic 
since it might nurture generalizations that are not well founded in the reality of EU decision making. Especially models within the booming branch of spatial games often do not capture the most important features of the empirical situation under scrutiny.

The conflicting interpretations of the codecision procedure might serve as an illustration why the empiricism typical of most non-rational choice institutionalists should play a more prominent role in the process of EU theorizing. Moser (1997) for instance demonstrates in contrast to Tsebelis (1997) that the latest substantial institutional innovation empowered the legislature in comparison with the Council of Ministers. As Kaiser's (1996) empirical study shows, this power shift is, however, not due to limitations on the Council's power to propose, as Moser's interpretation of the Treaty on European Union suggests. It seems largely to be a consequence of the costs that are involved with the use of vetos and inflexible bargaining positions. ${ }^{7}$ This finding shows that the strategic use of institutions rather than the power potential arising from a legalist interpretation of the constitutional rules should be one of the key topics in rationalist reasoning on EU institutions.

One exception to the formalistic trend is the two-level game literature on European integration. Schneider \& Cederman (1994) show how member states use domestic institutions to strengthen their bargaining stance in the negotiation rounds of the European Council. A possible threat involving a formal rule is modeled in the referendum game where a laggard state can hint at popular resistance towards further integration in order to obtain a less favorable treaty. ${ }^{8}$ Hug's (1997) discussion of the feasibility of direct democracy at the level of the European Union reiterates this point and demonstrates that the future development of the organization depends heavily on how future procedures are designed. If referendums are binding, constituents at the domestic level are more likely to go along with the opinion of their preferred party than in a situation of a non-committing vote (Hug \& Sciarini 2000).

However, rational choice research has not yet devoted sufficient attention to the impact of informal institutions (Schmidt 2000). One example is the possibility to employ a potential government crisis to bolster a threat in the realm of the European Union (Schneider \& Cederman 1994). Another example of the considerable influence of informal rather than formal rules is seniority, which influences not least the way in which the European Commission is formed or how members of the European Parliament are selected (Schneider 1997b). Finally and probably most importantly, no rationalist work on the impact of cultural factors on the integration process exists. 


\section{Historical/sociological}

The historical and sociological institutionalist approaches take a different cut on institutional dynamics and decisionmaking in the EU. In historical institutionalism the focus is on the ways prior institutional commitments condition further action, limit the scope of what is possible, and cause agents to redefine their interests (Bulmer 1994; Pierson 1996). As Bulmer states, 'political struggles are mediated by prevailing institutional arrangements' (1994: 355). Institutional and policy change become 'path dependent' as actors define their preferences endogenously, based upon what has occurred in the past. The image is one of a ratchet, in which institutional arrangements are winched into place slowly over time, thus constraining human behavior. History creates context, which shapes choice.

Member state preferences are conditioned and shaped by what they have already agreed to within Europe. Therefore, causality flows both ways - while agents choose institutions, institutions then constrain agents. EU institutional and policy development may ultimately follow one of any number of 'paths', and historical institutionalism does not show favoritism for one path over another. There is no reason why agents may not subsequently alter institutional arrangements to better suit their needs, but extant research points to the 'stickiness' and longevity of prior structural arrangements.

This is illustrated in work by Pierson (1996). He argues that intergovernmentalism neglects the evolution of cooperation over time and the importance of past decisions on interstate negotiations. Gaps emerge in member state control over institutional evolution, and these gaps are extremely difficult to close. Using the development towards a European social policy as an illustration, he shows the path-dependency of collaboration within the EU: 'In a number of instances, the short-term preoccupations of institutional designers have led them to make decisions that undermined long-term member-state control'. The ubiquity of unintended consequences, the autonomy of supranational institutions, and the instability of policy preferences in member states are further factors that have contributed to the inadvertent loss of control.

This work is about the autonomy of supranational institutions from member state principals, and represents an implicit extension of the recent thinking by comparativists about state autonomy from domestic social forces (Skocpol 1985). Pierson points out that member state power is increasingly constrained by a 'partial but nonetheless significant development of European-level social policy' (1996: 156).

Pierson's essay is a response to the intergovernmentalist notion of state choice, and he uses the language of choice in delineating initial institutional arrangements. The implication is that member state preferences continue to be defined externally to the integration process - in other words they are less 
influenced by the development of EU institutions and policies than purely non-rational choice theorists would have us believe. Although Pierson does suggest that 'altered circumstances' (1996: 140) might force a change of governmental policy preferences, he also places emphasis on the partisan sources of preference. The inference is that exogenous preference formationmember state governments seeking to maximize national benefits rather than achieve a common solution in the 'European interest' - is still an important source of motivation. ${ }^{9}$ Thus, as he acknowledges (1996: 131), his research straddles the rationalist/non-rationalist divide.

Historical institutionalists differ over the role of culture in institutional influence, however. Where Pierson or Immergut (1992) see constrained rational actors, Armstrong \& Bulmer (1997) give emphasis to the different aspects of culture within European organizations such as the Commission. Historical institutionalists also differ over the issue of power. Pierson's discussion of historical institutionalism at the EU level omits the profound importance of structural bias, which is an important aspect of the historical agenda (Hall \& Taylor 1996: 940-1; Skocpol 1985; Armstrong \& Bulmer 1997: 52). The structure of supranational institutions and policy competence privileges certain types of policy over others, and by extension, certain actors over others.

The normative aspect of new institutionalism is evident here: institutions are not necessarily the product of neutral bargaining or efficient historical evolution. They have ideas built into them, which then influence the chances of agents. For example, the market orientation of European policy, and the existence of producer and consumer (DGIV) directorates with shared competence over policy marginalizes non-market interests. The dominant mode of policymaking has been negative, reflecting both the ascendant normative bias of liberalism and the structure of EU institutions, which privileged negative over positive integration. ${ }^{10}$

Therefore, along these two dimensions at least - power and culture it is possible to distinguish among historical institutionalists working on European-level politics. In general, those closest to the rationalist camp discount culture and see institutions as power-neutral; those closest to the sociological camp take culture into account and see the institutions as having important implications for the power of social groups.

The agency role of EU actors is also crucial to an understanding of the historical institutional basis of policymaking (among others, see Cram 1997; Armstrong \& Bulmer 1997; Pierson 1996; Burley \& Mattli 1993). There is much agreement that the European Commission and the European Court of Justice (ECJ) have actively constructed a European competence in important ways, through rulings, proposals, and alliances with actors at various levels 
across the EU. This activism may be an unwelcome byproduct of principalagent delegation, because as we stated earlier, agents sometimes have their own agendas. In the case of the Commission, this activity is ongoing through an identification of new issues, proposed solutions, and establishment of alliances. Throughout its work, the Commission strives both to legitimize itself and to create a demand for European level public goods that might not be created by principals acting jointly. Again, the effect of this is (often very slowly) to shift or create preferences, strategies, interests, and identities, which would not have been the case without supranational agency activism.

Although Europeanists working from a historical institutionalist perspective tend to focus on the EU level, there is a much larger comparativist literature using the historical approach at the level of the nation state. Numerous scholars have examined the unique economic and political traditions which color state responses to social demands or external change (see the contributors to Evans et al. 1985; Hall 1986; Schmidt 1995; Crouch 1993; Katzenstein 1985; Putnam 1993). For example, the similarities in corporatist arrangements among small European states distinguished their responses to economic change from those of the large industrial states (Katzenstein 1985). One of the shortcomings of historical institutionalism is its failure to integrate the effects of institutions over time at these two levels. As it becomes increasingly difficult to disentangle the mutual influences of the member state and EU levels, historical institutionalist research should endeavor to examine the interaction of institutions between the supranational and national polities.

In sum, historical institutionalism, while not a coherent body of thought, stresses the role of prior commitments and institutional and policy stickiness in the process of European integration. Historical institutionalism does not predict movement toward or away from integration; rather it predicts that agency rationality, strategic bargaining, and preference formation are conditioned by institutional context. European integration is a cumulative process, where prior decisions form a basis upon which new decisions are made. In the view of some theorists, historical institutionalism also infers a relationship between organizational culture and political outcomes (Armstrong \& Bulmer 1997), and sees an important structural bias on the part of institutional design (Hall and Taylor, 1996; Armstrong \& Bulmer 1997), which privileges some actors over others.

Sociological institutionalism has also contributed important insights to European integration studies and there seems to have been a veritable explosion in recent years in the number of scholars taking a broadly sociological or constructivist approach to this subject (see Joergensen 1997; Wiener 1998; Christiansen et al. 1999). This trend builds upon scholarship in international 
relations which has sought to identify normative and cultural mechanisms by which both state behavior and state identity are constrained or constructed, and additionally how identity itself influences state interests and practices, as well as international normative structures. The work in this area has sought to counter the rationalist thread linking both neoliberal institutionalism and neorealism (for an excellent overview, see Katzenstein 1996; Jepperson, Wendt \& Katzenstein, 1996; also, Wendt 1992, 1994; Ruggie 1998; Finnemore \& Sikkink 1998; Risse-Kappen 1995).

Sociological institutionalism in European studies has begun to make inroads in the theoretical landscape once dominated by variants of intergovernmentalism and supranationalism (for a review of the literature see Wind 1997: 24-32). Scholars have examined the enlargement of the EU and NATO (Fierke \& Wiener 1999), European citizenship (Wiener 1998), regionalism and European integration (Christiansen 1997), and domestic-European relations (Larsen 1997; Holm 1997; Laursen 1997) among others. This literature, like the international relations scholarship before it, is concerned partly with how state behavior is shaped or constrained in ways not captured by rationalist theories and partly about how identity is constructed. Thomas Diez, for example, drawing on Ole Wæver, asserts that 'Europe has become a reference point embedded in all national identity constructions' (Diez 1999: 10).

Constructivists have taken the notions of history, institutions, norms, ideas, and culture well beyond the point at which historical institutionalists are willing to go, raising them to the level of independent variables and problematizing a number of key concerns that rationalists take for granted. Some of the institutionalist research that fits this general category has examined the role of separate European state cultural traditions, which also produce 'institutions', though not necessarily in the sense intended by historical institutionalists. The reason for this bias is that culture has been implicitly defined as a state phenomenon, informing national actors in similar ways, though insights from organizational culture may equally be applied to specific groups or organizations.

Significantly, this research is at odds with the findings of sociological institutionalists more generally, who focus on organizational isomorphism as a response to the spread of western culture. The claim is that rational instrumentality in terms of markets and bureaucracies has forced adaption among organizations in otherwise very different contexts. It is the need for external cultural legitimation, rather than finding the most functionally-efficient response to local needs, that has forced adaptation (Meyer \& Rowan 1991). Thus, Finnemore (1996) points out that the sociological institutionalist literature tends to focus on the homogenizing effects of an emergent 'world 
culture,' (although she finds evidence of continuing contestation between cultural norms and values; 1996: 341).

Europeanists might usefully adapt concepts from the sociological perspective to explore how certain features of a 'regional culture' attract member states - such as a European model of capitalism, social democracy, and (during the Cold War) civilian power status. Some of these common cultural features in Europe have roots extending well back in history - such as JudeoChristianity and the Enlightenment - and contribute to what might be called a Western civilizational character (as Turkey knows to its chagrin; on civilizational conflict see Huntington 1993). It seems fairly clear that these features of the EU have attracted new members, particularly from southern and eastern Europe, who are eager to bolster their legitimacy as developed states of the West. We could examine whether their choice has been governed more by this need to belong or by the economic benefits they calculated would flow from membership. Those interested in theorizing about the reasons for regional integration often overlook the normative attraction of 'Europe' in the hurry to provide functionalist explanations of institutional reform or common policies.

On the other hand we could turn this research question around and ask instead, why has the EU itself tried to emulate states by developing statelike features, such as citizenship? Organizational isomorphism has affected the behavior of the EU as well as of European states, not least in order to provide a gloss of legitimacy to supranational governance. At the same time, the welter of criticism of the EU continues, based on the notion that it is illegitimate when compared to the state. The contested terrain of legitimate governance is apparent in the curious disjuncture between the British and Italian views of EMU: the British see it as de-legitimizing, the Italians see it as legitimizing.

Studies of European political economy have noted the enduring differences between state traditions in Europe and the importance of them in determining responses to change (see especially Crouch 1993; Crouch \& Streek 1997). The nature of domestic industrial relations arrangements, for example, based upon distinct cultural traditions, separate modes of capitalism, differential state-society relations, and so forth, have an important impact upon how actors respond to a variety of external challenges, including opportunities or demands for integration. Nationally-rooted cultural features 'establish a system of common reference' among actors, including their perceptions of the outside world, and they also establish a common identity rooted in both history and anticipated future (Zetterholm 1994: 4-5). This differentiation acts as a cross-cutting influence to the system-wide influences of social democracy, neo-liberalism, or some other motivating ideology. 
For example, although firms across Europe are ostensibly organized to maximize profits, in reality there are very different motivating principles depending on the cultural landscape in which the firm is located. Where the state reaches deep into society, owning monopoly enterprises and reproducing hierarchical relationships, the reaction to change (or the possibility of change) is likely to be far different than for liberal states. State ownership of monopolies and protection of national firms tends to fossilize national policy communities of bureaucrats, producers, and national parliaments in such a way that they are resistant to change from both inside the state (consumer groups, new producers, and 'generalist' ministries) and outside the state (foreign producers, the EU, and other international organizations). Although liberalization may be gaining credibility and legitimacy across western Europe (and firms are therefore re-organizing to be able to face greater competition), distinct national political-economic institutions and values that mitigate against full liberalism continue to hold sway.

One interesting issue raised by the sociological institutionalist approach is how these distinct national cultural settings change as liberalism and competitive practices gain legitimacy more widely. Indeed, the contested nature of legitimate practices in European capitalism means that sociological influences act at cross-purposes. More than one 'institutional environment' is acting upon agents and organizations, sending them conflicting signals about legitimate behavior.

Therefore, from the sociological institutionalist perspective, integration depends crucially on cultural and cognitive variation, and consequently the impact of values, beliefs, and identities on actors' responses to integrative challenges. This variation may occur along professional lines, where groups of professionals from different EU member states begin to respond in similar ways to proposed or agreed policies; it may occur within organizations such as the European Commission; it may occur along national lines, where firms in an Anglo-American context have different views of markets than firms in a Rhineland context (see Madsen 1994; Plaschke 1994; Streek 1997); it may occur at the subnational level, where citizens in one part of a country may have different views of the appropriate nature of state-society relations than citizens in another part of the country (Putnam 1993).

The key underlying assumption is that cognitive boundaries add transaction costs to cooperation, whether these links are founded in language, faith, geography, 'epistemic professionalism', or some other bond which assigns common meaning and value to human experience. Cultural persistence may be the result of external pressure (functional need or the desire for rewards) or internalization of norms. Alternatively, it may be caused by transmission of 'an exterior and objective reality' in which those cultural meanings that have 
wide significance in society are 'enculturated' into succeeding generations (Zucker 1991). These commonalities solidify over time, and so sociological institutionalism shares with historical institutionalism this important focus upon the temporal aspects of institutions. Moreover, as we move from historical institutionalism to sociological institutionalism, we see a tendency to assume that institutions become internalized and part of agent identity. Institutions become increasingly important independent causes of outcomes whether these are institutional design/change decisions or policy decisions.

\section{Methodology and theory: A tentative research agenda}

In this section we set out some of the methodological issues that must be addressed when applying the new institutionalisms to European integration studies. A tentative research agenda is also set out. We take as a starting point the notion that all our new institutionalisms are part of the scientific enterprise. Moreover, we follow King, Keohane, and Verba's point that where the objective is to gain knowledge through empirical research and the search for patterns, rules of inference should be followed. 'Inference, whether descriptive or causal, qualitative or quantitative, is the ultimate goal of all social science' (1994: 6, 34). Our research, whether from the rational choice, historical, or sociological perspectives, deals with uncertainty and tries to make descriptive, explanatory, or causal inferences about the nature of European integration.

This is perhaps the starting point for an understanding, if not reconciliation, between the new institutionalisms. It follows from the point above that it is the influence of institutions on outcomes that will be a principle area of research. Institutions, conceived as those formal and informal mechanisms that produce regular patterns of social behavior, act as both independent and intervening variables in this research. The dependent variables include such outcomes as common policies, reform of the supranational institutions, enlargement, and many other practical questions facing the European Union.

Much has been made of the differences between the methodologies of the different institutionalisms, especially qualitative versus quantitative research and formal deductive theorizing versus inductive case-study oriented thick description. These different approaches are often (though not of necessity) associated with a particular type of institutional approach.

Rational choice institutionalism has largely focused on formal rules and the actor's potential influence within a particular strategic setting. Institutions are like mazes or hurdles - something to be negotiated on the way to a prize which everyone is seeking. The most important result is arguably the rigorous demonstration that power in the European Union is shared in a complex 
and often counterintuitive way between competing actors. The approach assumes that actors understand the possibilities and limitations that the diverse decision making rules have created. More particularly, rational choice institutionalism suggests that actors adapt their behavior to these institutions and use them strategically.

The methodology of rational choice institutionalism has mainly been deductive, formal, and universalist. It has tended not to examine individual cases, and this has led (as we stated earlier) to conflicting interpretations of the same events, such as the influence of the codecision procedure. As Green \& Shapiro (1994) point out, a major weakness of rational choice theorizing is this lack of empiricism. This is compounded by the occasional tendency to engage in post-hoc theory adjustments when empirical data are found to contradict the model and by the lack of attention to competing theories (neither of these latter two tendencies are limited to rational choice theorists, of course).

Historical institutionalism, by contrast, starts from the premise that human decisions are much more sticky. They create a web of rules and patterns of behavior which essentially 'regularizes' human conduct in such a way that certain options, choices, or preferences are not entirely viable. However, some aspects of historical institutionalism are closely related to rational choice institutionalism. For example, many historical institutionalists would not deny that agents intentionally create institutions to solve collective action problems. Moreover, within certain constraints, historical institutionalists do believe that agents behave rationally, order preferences (to the extent they are able to) and act strategically to achieve beneficial outcomes. As institutions become more familiar, or as social activity conforms to them, historical institutionalists would predict that actors' choices in terms of preferences and strategies would narrow.

Finally, sociological institutionalism gives primacy to the ways human behavior is conditioned at a deeper, cultural level. Institutions are not mazes or hurdles, external to the actor; they are internal, subconcious, pre-rational. Cognitive links created by common experience link humans together, which lowers the transaction costs of determining how to act in particular situations. These commonalities and understandings can only be created over time, and thus sociological and certain historical institutionalist approaches are closely related.

Certain elements of historical institutionalism are closely related to sociological institutionalism, notwithstanding the assertion of differences between the structural and constraining features of the former and the cognitive and cultural features of the latter. For example, institutions such as the state and its bureaucracy are historical artifacts - they structure and con- 
strain social elements. Yet they are also endorsed and legitimized by cultural attributes, and over time the state institutions help to reinforce culture and condition responses to potential and real change. The interaction is twoway - constraints and cognitive processes are intertwined. Over time the mutual impact of culture and historical institutional evolution are impossible to separate.

The methodology of historical and sociological institutionalism in European integration studies has been empirical and case-study oriented. Whether intentionally or not it has tended to follow the route of 'analytical induction and historically grounded comparisons' (suggested by Evans et al. 1985: 348 with respect to the state). This has led to a rich collection of descriptive analyses of events but with little theoretical generalization and even less quantitative data manipulation. Conceivably, quantitative methods could be applied to determinations of institutional influence but to date this has not occurred in European studies.

Empirical case studies have the distinct advantage that they are descriptively rich and quite precise in their explanation of unique events. However, they suffer from the defect that the very detail may obscure the relative importance of causal variables. Moreover, one-at-a-time case studies do not permit valid generalizations as long as no causal model exists to assist in the inevitable task of counterfactual reasoning. ${ }^{11}$ Researchers could potentially overcome this by gathering a number of case studies together. The European Union is a unique institution, but this uniqueness should not be an excuse for a lack of theoretical sophistication and methodological rigor. On the contrary, most institutionalist research questions on the European Union refer to a selection of similar events and thus invite comparativist analysis either across policy areas, across member states, or across time (see for example, Hix 1998).

Consistent with the general discussion above, institutionalist contributions to the study of the European Union diverge in at least two important ways across the different theoretical approaches. First, the competing approaches differ in the intensity with which they try to establish causal explanations of the interrelationship between actors, context and rules. Sociological and historical institutionalisms pay particular attention to the contexts which, in their opinion, help to shape policy change, mediate between integrative actors, and alter conditions in which integrative decisions are reached. In this paradigm (particularly the sociological institutionalist one), structure is ontologically prior to agency. In rationalist research, context matters less. Although different environments present diverging incentive structures, individuals are still conceived of as reacting basically in the same strategic fashion. 
A second difference lies in the way the approaches deal with evidence. While illustrations and casual stories are often considered as a sufficient base to bolster a rationalist argument, historical and sociological institutionalist explanations are much more driven by empirical findings. When rationalists take the empirical task more seriously, they often employ 'positivist' theories (for a convincing example, see Franchino 2000). On the other hand, while many historical and sociological institutionalists assimilate quantitative or qualitative evidence in a positivist manner, there is often a normative element to theorizing which stresses that institutions produce outcomes of certain types, due to the structural bias inherent in institutions.

What should we make of this methodological pluralism? One advantage of formal modeling, whether it involves fully or only boundedly rational actors, is that it forces precision into an argument. In other words, strategic rationality, broadly conceived, uncovers some of the problems of inductive reasoning. It lends precision to a theoretical argument and allows formal theorists to challenge common sense interpretations. The necessary complement to a convincing empirical strategy (Moravcsik 1997) is a model, rational or non-rational, which establishes causal links between variables and from which testable hypotheses are derived. While we agree with many rational choice critics that only empirically grounded examinations allow us to move further in the social sciences, we also believe that it is urgent to establish a solid theoretical model before engaging in qualitative or quantitative tests. Without a solid grounding of the basic hypotheses, any empirical work remains incomplete and shaky.

Therefore we encourage those working in a historical and sociological framework to raise their theoretical aspirations by working with models that are as explicit and generalizable as possible, and they should endeavor to generate as many observable implications as feasible in their empirical work. Ideally, they should link a number of cases in a comparative framework, testing an explicit model.

Analytical models are indispensable in the development of institutionalist theories even if they are dealing with potentially unique constellations. Yet, any model in an applied setting such as the EU decisionmaking arena should be empirically informed and accompanied by a sound test. Without testing and confirmation of hypotheses with empirical data, these hypotheses must remain subject to question. Some work in non-rational choice institutionalism leads us in this direction. We believe that this merger between theoretical rigor and substantive tests of the deduced hypotheses is the main comparative advantage of a revised institutionalism.

Finally, we believe that it is crucial that theorists take into account alternative theoretical explanations to the puzzles they are addressing, and this 
applies primarily to rational choice theorists, who would be forced to relax their universality claims. As two well-known institutionalists put it,

It is not obvious that any one approach is superior to the others in capturing the complexities of change. There are several stories to be told and a necessary humility associated with the telling of any one of them. (March \& Olsen 1998: 21)

How should we treat these competing views of institutions? Is there something wrong with theoretical and methodological pluralism? We believe in accordance with Ostrom (1991), Norgaard (1996) and others that there is some potential for theoretical convergence although we do not eschew pluralism in either theory or methodology. First and foremost, the understanding of institutions converges to some extent, with all approaches perceiving them as both constraints and opportunities.

Second, no approach has an inherent bias towards certain levels of analysis. While it is sometimes argued that rationalist institutionalists focus on grand bargains in the European Council, such a theoretical focus is not a necessity. On the contrary, recent institutionalist research points out that power sharing is increasingly important despite the ultimate predominance of intergovernmentalist institutions such as the European Council (Schneider 1995).

One possibility for theoretical convergence is the relaxation of the rationality assumption in rational choice modeling. This is particularly the case with evolutionary game theory which studies the emergence of behavioral patterns among boundedly rational and habit driven actors (Weibüll 1995). Ostrom similarly argues that rational decisionmaking occurs within a rule-bound context. 'Rather than conceptualizing rule-governed choice as more important than rational choice, a general approach would attempt to explain how both rules and anticipated consequences affect behavior and outcomes' (Ostrom 1991: 239). Norgaard takes this a step further and advocates an approach that 'both appreciates that human beings are intentional and reflective irrespective of context, and that people's preferences are shaped by experiences and thus by cultural legacies, and, indirectly, by the institutions constraining and enabling social interaction' (1996: 32). This 'reasonable rationality' relaxes many assumptions about the materialist, welfare-optimizing nature of human choice, but in doing so it risks tautology by labeling everything as rational.

Another possibility is to think more carefully about the temporal 'level of analysis'. Rational choice institutionalism's focus is primarily upon short time-horizon bargaining scenarios, even if these games may be iterated. Historical and sociological institutionalism, by contrast, assume that the institutional influences on actor behavior are the product of a long gestation 
period. Since these institutionalists are pre-programmed to begin their analysis from a structural perspective, they take a longer term view of institutions by definition. Structure may constitute agents, but it often takes a long time for structure to evolve. Yet if these theorists examine a one-off decisionmaking scenario, they may find that actors behave rationally within the confines of institutional context. In other words, against 'the background of habitualized activity opens up a foreground for deliberation and innovation' (Berger \& Luckmann, 1967: 71).

Conversely, rational choice institutionalism may find that the long-term consequences of repeated interactions are that some forms of behavior are deemed legitimate in a bargaining context, while others are illegitimate. Unless institutionalized practices are rejected, time tends to internalize their effects so that agents have less propensity to reflect consciously on their efficacy. Over time, institutions become less susceptible to agent calculation. On the contrary, they are 'internalized' and 'frozen' into the decision-making system, leading to habit-driven rather than self-reflective behavior (for norm internalization, see Finnemore \& Sikkink 1998).

Finally, agents may act differently depending on what is at stake. Plausibly, as the perceived stakes rise, agents will becomes more 'rationalist' in their actions as they carefully consider the costs and benefits, risks and opportunities of certain outcomes. Likewise, in less costly, more mundane activity, agents may be more likely to act on the basis of 'appropriateness' (March \& Olsen 1998) - that is, appropriateness defined as what is contextually legitimate. In other words they may ask how they 'should' respond to the situation.

Institutionalists of all stripes should begin to think more carefully about ways to discern between the explanatory power of the institutionalisms, adding to this first cut. For example, we may ask whether European integration occurs because of a rational calculation of anticipated benefits by member states, or because the norms embodied in the EU - such as peaceful relations, democratic government, and ever closer union - now exert a supranational legitimacy. Given the contested nature of European integration we sometimes forget the norms that unify the states of Europe.

With these thoughts in mind, we offer a set a guiding questions that could serve to channel future research in this area. First, what kind of institutions matter in the context of European integration and how do they affect behavior by agents at all levels of decision making? Second, under what circumstances do certain institutions arise, and how much can we attribute in this emergence to intentional behavior and the passage of time? Third, how are institutions altered or maintained, and how do EU institutions affect institutions at other levels and vice versa? Fourth, how do EU institutions impact on decision 
making? Table 2 elaborates on this research framework and suggests possible lines of inquiry generated from the foregoing discussions and extant research on institutions.

\section{Conclusion}

This article has explored the common ground between the separate strands of institutionalist thought, and has attempted to go beyond the tautological assertions that relaxed rationality assumptions, be it in the form of 'reasonable rationality' or 'rule-bound rationality' can reconcile the two schools. We believe that the theoretical differences between the competing schools of thought have been overstated. Epistemological divergences, by contrast, have not yet played a major role in the debate.

We show how a certain degree of reconciliation based on a common research agenda can be reached. The article particularly suggests that the 'thick description' characterizing sociological and historical institutionalism is at least partly compatible with rationalist thinking. Equally, large- $n$ studies may lead to the conclusion that preferences, strategies, or outcomes are contingent upon historical or social processes. One possible means of accomplishing this reconciliation is to examine through case study method an episode of institutional change or policy formulation by attempting to control for the influence of institutions on actor preferences and strategies. In other words, the study could strive to postulate what actors' preference and strategies would have been in the absence of institutions, and compare this to the observed outcome.

A methodological convergence, however, will only become likely under two conditions. First, applied rationalists have to give in to the historical and sociological institutionalists demand for empirical precision. Without a meaningful referent in reality, any hypothesis remains, to quote David Singer, an 'insight without evidence'. Second, non-rational choice research should also acknowledge that models, be they rational or non-rational, are an indispensable method to derive hypotheses. We believe that many case studies could be improved if they are more theoretically guided and more consciously seeking to detect those causal mechanisms that matter. From all perspectives, the future of institutionalism in integration studies thus looks daunting. In our view, the challenge that we have analyzed in this article is, however, also exciting and promising. 
Table 2. Current research practice (RP) and possible future research practice (FP)

\begin{tabular}{|c|c|c|c|}
\hline Questions & Rational choice & Historical & Sociological \\
\hline $\begin{array}{l}\text { What kind of } \\
\text { institutions } \\
\text { matter? }\end{array}$ & $\begin{array}{l}\text { RP: Mainly } \\
\text { formal } \\
\text { institutions } \\
\text { FP: Widening of } \\
\text { focus to informal } \\
\text { rules and cultural } \\
\text { practices }\end{array}$ & $\begin{array}{l}\text { RP: All } \\
\text { decisionmaking } \\
\text { institutions at the } \\
\text { EU and national } \\
\text { levels. } \\
\text { FP: Role of culture }\end{array}$ & $\begin{array}{l}\text { RP: Identity, } \\
\text { shared experience } \\
\text { and attached } \\
\text { symbols, myths } \\
\text { etc. } \\
\text { FP: Organizational } \\
\text { rather than national }\end{array}$ \\
\hline $\begin{array}{l}\text { Relationship } \\
\text { between } \\
\text { institutions and } \\
\text { strategies }\end{array}$ & $\begin{array}{l}\text { RP: Exploration of } \\
\text { power potential } \\
\text { FP: Strategic use } \\
\text { of institutions. }\end{array}$ & $\begin{array}{l}\text { RP: Constraining } \\
\text { effect of } \\
\text { institutions. } \\
\text { FP: process of } \\
\text { assimulating } \\
\text { institutions over } \\
\text { time. }\end{array}$ & $\begin{array}{l}\text { RP: Nationally- } \\
\text { based } \\
\text { norms/values } \\
\text { color responses } \\
\text { FP: Cross-cutting } \\
\text { influence of non- } \\
\text { national norms. }\end{array}$ \\
\hline $\begin{array}{l}\text { What causes } \\
\text { institutions to } \\
\text { arise and change? }\end{array}$ & $\begin{array}{l}\text { RP: Reliance on } \\
\text { selection models } \\
\text { or transaction } \\
\text { cost arguments } \\
\text { FP: Institution } \\
\text { creation as a } \\
\text { bargaining } \\
\text { process }\end{array}$ & $\begin{array}{l}\text { RP: Functional } \\
\text { need, but habit, } \\
\text { convenience, } \\
\text { shortcuts also. } \\
\text { FP: Role of actor } \\
\text { choice, agency } \\
\text { initiative. }\end{array}$ & $\begin{array}{l}\text { RP: Linked to } \\
\text { identity and } \\
\text { common } \\
\text { interpretations. } \\
\text { FP: Role of } \\
\text { external pressures } \\
\text { or shocks. }\end{array}$ \\
\hline $\begin{array}{l}\text { Role of } \\
\text { intentionality }\end{array}$ & $\begin{array}{l}\text { RP: Actors are } \\
\text { fully rational } \\
\text { FP: Extension to } \\
\text { models with } \\
\text { limited rational } \\
\text { actors }\end{array}$ & $\begin{array}{l}\text { RP: Intentionality } \\
\text { crucial to creation } \\
\text { of institutions. } \\
\text { FP: How } \\
\text { intentionality is } \\
\text { modified by } \\
\text { institutional } \\
\text { history. }\end{array}$ & $\begin{array}{l}\text { RP: Intentionality } \\
\text { largely absent. } \\
\text { FP: Process of } \\
\text { organizational } \\
\text { adaptation to } \\
\text { external forces. }\end{array}$ \\
\hline Role of history & $\begin{array}{l}\text { RP: History plays } \\
\text { only a role as it } \\
\text { affect short-term } \\
\text { interactions } \\
\text { FP: Modeling } \\
\text { specific } \\
\text { 'historical' } \\
\text { influences }\end{array}$ & $\begin{array}{l}\text { RP: Constraining, } \\
\text { structuring role. } \\
\text { FP: Internalizing } \\
\text { effect over long } \\
\text { term. }\end{array}$ & $\begin{array}{l}\text { RP: Cognitive } \\
\text { links harden } \\
\text { between episodes } \\
\text { of externally- } \\
\text { induced change. } \\
\text { FP: Effect of cross- } \\
\text { cutting } \\
\text { sociological } \\
\text { influences. }\end{array}$ \\
\hline
\end{tabular}




\section{Acknowledgements}

Previous versions of this paper have been presented at the 1997 research session of the European Consortium of Political Research (ECPR), University of Bergen, 18-21 September 1997, and the workshop on the 'Rules of Integration', University of Konstanz, 6-8 October 1998 We would like to thank the ECPR and Thyssen Foundation for their assistance and gratefully acknowledge the traveling support and hospitality of the Department of Comparative Politics at the University of Bergen. The article has greatly profited from our discussions with different participants, including Simon Bulmer, Jeff Checkel, Laura Cram, Johan P. Olsen and Susanne Schmidt. We would also like to thank Thomas Plümper, George Tsebelis and two anonymous reviewers for extensive comments. Our project represents not only a perhaps futile attempt to find a synthesis between different research traditions in European studies, but also a more personal effort by two scholars who try to understand each other's research. The article could thus not have been written without a minimal level of tolerance. It might have helped that we were both socialized in our colleague's research tradition: ironically, both of us decided against the cultural mainstream, with Aspinwall becoming a historical/sociological institutionalist and Schneider a diehard rationalist. Given our different understanding of the world, any remaining error should be attributed to either bad habits or suboptimal choices.

\section{Notes}

1. We believe that the label 'historical' is a misnomer since every social phenomenon can be attributed to the influence of history. As social scientists we should specifically delineate between important and unimportant historical influences. We recognise, however, that many social scientists use historical institutionalism as an independent category and we follow this convention.

2. The following discussion extends the useful classification in Imbusch (1997).

3. Extending Becker's framework to explicitly strategic situations is feasible. It should, however, be kept in mind that adding complexities to an already complicated model yields a considerable indeterminacy in the selection of the appropriate solution to a game.

4. This is the reason why rational choice institutionalism has also been labeled the theory of strategic integration (Moser and Schneider 1997).

5. Rationalist studies on European integration have their predecessor in voting power studies where the ex ante power of individual actors is assessed (e.g., Brams \& Affuso 1976). As Garrett \& Tsebelis (1996) correctly point out, this kind of study largely focuses on individual institutional actors, thereby missing the increasing tendency towards power sharing and ignoring institutional complexities of decision making in the European Union. Some recent work tries to account for institutional aspects. One problem with these revisions is that they implicitly assume an unambiguous impact of institutions on the actors' voting 
power. As the spatial voting literature has repeatedly shown, such a uniformity is, however, unrealistic if actors' preferences are allowed to vary. Three proponents of the voting power literature have recently shown that these problems cannot be solved through the inclusion of ideological consideration since the voting power indices are highly sensitive to small variations in the actors' preferences (Lane, Berg \& Maeland 1997). Only indices that are based on spatial models are able to overcome this problem (see Steunenberg, Schmidtchen \& Koboldt 1999).

6. For a related point, see Snidal (1986).

7. Kaiser (1996) attributes Tsebelis' (1997) interpretation that the European Parliament has lost influence under codecision in comparision to cooperation to his failure to recognize that the European Commission matters in the second reading and that, consequently, the influence of the Parliament is more limited than he conjectures in his analysis of this decision stage. Scully's (1997) attack on Tsebelis' interpretation raises similar points, but is unfortunately hampered by severe misinterpretations of strategic reasoning (Tsebelis and Garrett 1997).

8. Pahre (1997) similarly demonstrates that different forms of parliamentary involvement can be used strategically and affect a country's behavior at the international level.

9. This observation is, by the way, perfectly compatible with the rationalist literature on two-level games.

10. This has also been pointed out by Scharpf (1988) who would not consider himself a historical institutionalist.

11. The 'method' of counterfactual reasoning has recently been proposed as a means to overcome the small $n$-problem that characterizes theoretical explorations of many interesting social phenomena. It is often forgotten, however, that the number of cases can be raised in most research designs.

\section{References}

Almond, G. (1990). Discipline divided. Schools and sects in political science. Newbury Park: Sage.

Alter, Karen (1998). Who are the 'masters of the treaty'? European Governments and the European Court of Justice 52(1): 121-147.

Armstrong, K. \& Bulmer, S. (1997). The governance of the single European market. Manchester: Manchester University Press.

Arthur, W. B. (1994). Increasing returns and path dependence in the economy. Ann Arbor: University of Michigan Press.

Aspinwall, M. (1995). International integration or internal politics? Anatomy of a single market measure, Journal of Common Market Studies 33.

Axelrod, R. (1984). The evolution of cooperation. New York: Basic Books.

Becker, G. (1996). Accounting for taste. Cambridge, MA: Harvard University Press.

Berger, P. \& Luckmann, T. (1967). The social construction of reality: A treatise in the sociology of knowledge. Harmondsworth: Penguin.

Brams, S. \& Affuso, P. (1976).. Power and size: A new paradox. Theory and Decision 7: $29-56$.

Buchanan, J. (1979). What should economists do? Indianapolis: Liberty Press.

Bulmer, S. (1994). The new governance of the European Union: A new institutionalist approach, Journal of Public Policy 13: 351-380. 
Burley, A.-M. \& Mattli, W. (1993). Europe before the court: A political theory of legal integration, International Organization 47.

Calvert, R. (1994). The rational choice theory of social institutions: Cooperation, coordination, and communication. In: J. Banks \& E. Hanushek (eds.), Modern political economy. New York: Cambridge University Press.

Campbell, J., Hollingsworth, R. \& Lindberg, L. (eds.) (1991). Governance of the American economy. Cambridge: Cambridge University Press.

Checkel, J. (1997). The europeanization of citizenship?, unpublished manuscript, ARENA.

Checkel, J. (2000). Constructing European institutions. In: M. Aspinwall \& G. Schneider (eds.), The Rules of Integration. Manchester: University of Manchester Press.

Cram, L. (1997). Policymaking in the European Union: Conceptual lenses and the integration process. London: Routledge.

Christiansen, T. (1997). Reconstructing European space: From territorial politics to multilevel governance. In: K. E. Joergensen (ed.), Reflective Approaches to European Governance (pp. 51-68). London: Macmillan.

Christiansen, T., Joergensen, K. E. \& Wiener, A. (eds.) (1999). Constructivism in European studies, Journal of European Public Policy (special issue) 6.

Crombez, C. (1996). Legislative procedures in the European community, British Journal of Political Science 26: 199-228.

Crombez, C. (2000). The Treaty of Amsterdam and the codecision procedure. In: M. Aspinwall \& G. Schneider (eds.), The rules of integration. Manchester: University of Manchester Press

Crouch, C. (1993). Industrial relations and European state traditions. Oxford: Clarendon.

Crouch, C. \& Streek, W. (eds.) (1997). Political economy of modern capitalism. London: Sage.

David, P. (1985). Clio and the econometrics of QWERTY, American Economic Review 75: 332-337.

Diez, T. (1999). Riding the AM-track through Europe. Or, the pitfalls of a rationalist journey through European integration, unpublished paper, Copenhagen Peace Research Institute.

DiMaggio, P. \& Powell, W. (1991). Introduction. In: ibid. (eds.), The new institutionalism in organizational analysis. Chicago: University of Chicago Press.

Evans, P., Rueschemeyer, D. \& Skocpol, T. (eds.) (1985). Bringing the state back in. Cambridge: Cambridge University Press.

Fierke, K. M. \& Wiener, A. (1999). Constructing institutional interests: EU and NATO enlargement. In: T. Christiansen, K. E. Joergensen \& A. Wiener (eds.), Constructivism in European studies, Journal of European Public Policy (special issue) 6.

Finnemore, M. (1996). Norms, culture, and world politics: Insights from sociology's institutionalism, International Organization 50: 325-347.

Finnemore, M. \& Sikkink, K. (1998). International norm dynamics and political change, International Organization 52: 887-917.

Franchino, F. (2000). Control of the commission's executive functions, European Union Politics 1 (forthcoming).

Garrett, G. (1992). International cooperation and institutional choice: The European community internal market, International Organization 46: 533-560.

Garrett, G. (1995). The politics of legal integration in the European Union, International Organization 49: 171-181.

Garrett, G. \& Tsebelis, G. (1996). An institutional critique of intergovernmentalism, International Organization 50: 269-299.

Giddens, A. (1984). The constitution of society, Cambridge: Polity Press.

Giddens, A. (1976). New rules of sociological method. London: Hutchinson. 
Green, D. \& Shapiro, I. (1994). Pathologies of rational choice theory. New Haven, CT: Yale University Press.

Hall, P. (1986). Governing the economy: The politics of state intervention in Britain and France. Cambridge: Polity Press.

Hall, P. \& Taylor, R. (1996) Political science and the three new institutionalisms, Political Studies 44: 936-957.

Hix, S. (1998). The study of the European Union II: The 'new governance' agenda and its rival, Journal of European Public Policy 5: 38-65.

Holm, U. (1997). The French garden is no longer what it used to be. In: K. E. Joergensen (ed.), Reflective approaches to European governance (pp. 128-145). London: Macmillan.

Hug, S. \& Sciarini, P. (2000). Referendums on foreign policy: Do institutions matter in voter's decisions?, Comparative Political Studies.

Hug, S. (1997). Integration through referendums. In: P. Moser, G. Schneider \& G. Kirchgässner (eds.), Decision rules in the European Union: A rational choice perspective. London: Macmillan (also published as a special issue of Aussenwirtschaft 52: I-II).

Huntington, S. (1993). The clash of civilizations, Foreign Affairs 72: 22-49.

Imbusch, K. (1997). Die Entwickluhng des neuen Mittelmeeransatzes der Europäischen Union. Unpublished diploma thesis, Faculty of Public Administration, University of Konstanz.

Immergut, E. (1992). Health politics: Interests and institutions in Western Europe. Cambridge: Cambridge University Press.

Jepperson, R. (1991). Institutions, institutional effects, and institutionalism. In: W. Powell \& P. DiMaggio (eds.), The new institutionalism in organizational analysis. Chicago: University of Chicago Press.

Jepperson, R., Wendt, A. \& Katzenstein, P. (1996). Norms, identity, and culture in national security. In: P. Katzenstein (ed.), The culture of national security: Norms and identity in world politics. New York: Columbia University Press.

Joergensen, K. E. (ed.) (1997). Reflective approaches to European governance. London: Macmillan.

Kaiser, D. (1996). Institutionelle Wandel im Europäischen Politikprozeß. Europäisches Parlament und Kommission - Ende einer natürlichen Allianz. Diploma Thesis, Faculty of Public Administration, University of Konstanz.

Katzenstein, P. (1985). Small states in world markets: Industrial policy in Europe. Ithaca, NY: Cornell University Press.

Katzenstein, P. (1996). Introduction. In: ibid. (ed.), The culture of national security: Norms and identity in world politics. New York: Columbia University Press.

Keman, H. (1997). Approaches to the study of institutions. In: Bernard Steunenberg \& Frans van Vught (eds.), Political institutions and public policy. Dordrecht: Kluwer.

Keohane, R. \& Hoffmann, S. (1991). Institutional change in Europe in the 1980s. In: idem. (eds.), The new European community. Boulder, CO: Westview Press.

King, G., Keohane, R. \& Verba, S. (1994). Social inquiry: Scientific inference in qualitative research. Princeton: Princeton University Press.

Knight, J. (1992). Institutions and social conflict. New York: Cambridge University Press.

Koelble, T. (1995). The new institutionalisms in political science and sociology, Comparative Politics 2: 231-243.

Kreps, D. (1990). Corporate culture and economic theory. In: J. Alt \& K. Shepsle (eds.), Perspectives on positive political economy. New York: Cambridge University Press.

Lane, J.-E., Berg, S. \& Maeland, R. (1997). The power index method and the EU. In: P. Moser, G. Schneider \& G. Kirchgässner. (eds.), Decision rules in the European Union: 
A rational choice perspective. London: Macmillan (also published as a special issue of Aussenwirtschaft 52: I-II).

Larsen, H. (1997). British discourses on Europe: Sovereignty of parliament, instrumentality and the non-mythical Europe. In: K. E. Joergensen (ed.), Reflective approaches to European governance (pp. 109-127). London: Macmillan.

Laursen, J. (1997). Nordic ideas and realities. In: K. E. Joergensen (ed.), Reflective approaches to European governance (pp. 146-163). London: Macmillan.

Lindberg, L. \& Campbell, J. (1991). The state and the organization of economic activity. In: J. Campbell, R. Hollingsworth \& L. Lindberg (eds.), Governance of the American economy. Cambridge: Cambridge University Press.

Madsen, P. (1994). Is culture a major barrier to a single European market? The case of public purchasing. In: S. Zetterholm (ed.), National cultures and European integration: Exploratory essays on cultural diversity and common policies. Oxford: Berg.

March, J. \& Olsen, J. (1984). The new institutionalism: Organizational factors in political life, American Political Science Review 78.

March, J. \& Olsen, J. (1989). Rediscovering institutions: The organizational basis of politics. New York: The Free Press.

March, J. \& Olsen, J. (1998). The institutional dynamics of international political orders, ARENA Working Paper No. 5, April.

Mattli, W. \& Slaughter, A.-M. (1995). Law and politics in the European Union: A reply to Garrett, International Organization 49: 183-190.

Mattli, W. \& Slaughter, A.-M. (1998). Revisiting the European Court of Justice. International Organization 52: 177-209.

Meyer, J. \& Rowan, B. (1991). Institutionalized organizations: Formal structure as myth and ceremony. In: W. Powell \& P. DiMaggio (eds.), The new institutionalism in organizational analysis. Chicago: University of Chicago Press.

Moe, T. (1991). Politics and the Theory of Organization, Journal of Law, Economics, and Organization 7: 106-129.

Moravcsik, A. (1997). Overcoming the ' $N=1$ challenge': The case for greater rigor, ECSA Journal.

Moser, P. (1997a). A theory of the conditional influence of the European parliament in the cooperation procedure, Public Choice.

Moser, P. (1997b). The benefits of the conciliation procedure for the European parliament. In: P. Moser, G. Schneider \& G. Kirchgässner. (eds.), Decision rules in the European Union: A rational choice perspective. London: Macmillan (also published as a special issue of Aussenwirtschaft 52: I-II).

Moser, P., Schneider, G. \& Kirchgässner, G. (forthcoming). Decision rules in the European Union: A rational choice perspective. London: MacMillan (also published as a special issue of Aussenwirtschaft 52: I-II).

Norgaard, A. (1996). Rediscovering reasonable rationality in institutional analysis, European Journal of political research 29: 31-57.

North, D. (1981). Structure and change in economic history. New York: W.W. Norton \& Co.

Ostrom, E. (1991). Rational choice theory and institutional analysis: Toward complementarity, American Political Science Review 85: 237-243.

Pahre, R. (1997). Endogenous domestic institutions in two-level games and parliamentary oversight of the European Union, Journal of Conflict Resolution 41.

Payne, D., Mokken, R. \& Stokman, F. (1997). European Union power and regional involvement: A case study of the reform of the structural funds for Ireland. In: P. Moser, G. Schneider \& G. Kirchgässner (eds.), Decision rules in the European Union: A ra- 
tional choice perspective. London: Macmillan (also published as a special issue of Aussenwirtschaft 52: I-II).

Pierson, P. (1996). The path to European integration: A historical institutionalist analysis, Comparative Political Studies 29: 123-163.

Plaschke, H. (1994). National economic cultures and European integration. In: S. Zetterholm (ed.), National cultures and European integration: Exploratory essays on cultural diversity and common policies. Oxford: Berg.

Putnam, R. (1993). Making democracy work: Civic traditions in modern Italy. Princeton, NJ: Princeton University Press.

Risse-Kappen, T. (1995). Democratic peace - Warlike democracies? A social constructivist interpretation of the liberal argument, European Journal of International Relations 1: 491517.

Ruggie, J. G. (1998). What makes the world hang together? Neo-utilitarianism and the social constructivist challenge, International Organization 52: 855-885.

Scharpf, F. (1985). Die Politikverflechtungsfalle - Europäische Integration und deutscher Föderalismus im Vergleich, Politische Vierteljahresschrift 26: 323-356.

Scharpf, F. (1988). The joint-decision trap: Lessons from German federalism and European integration, Public Administration 66: 239-278.

Schmidt, S. K. (2000). A constrained commission: Informal practices of agenda-setting in the council. In: M. D. Aspinwall \& G. Schneider (eds.), The rules of integration. Manchester: University of Manchester Press.

Schmidt, V. (1995). The new world order, Daedelus 124: 75-106.

Schneider, G. (1994). Rational Choice und kommunikatives Handeln. Eine Replik auf Harald Müller, Zeitschrift für Internationale Beziehungen 1(2): 357-366.

Schneider, G. (1995). The limits of self-reform: Institution building in the European Community, European Journal of International Relations 1: 59-86.

Schneider, Gerald (1997). Choosing chameleons: The selection of the EU commissioners. Typescript, University of Konstanz.

Schneider, G. \& Cederman, L.-E. (1994). The change of tide in political cooperation: A limited information model of European integration. International Organization 48: 633-662.

Schneider, G. and Weitsman, P. (1995). Cooperation among equals: A theory of regional integration, Unpublished Paper.

Schneider, G., Weitsman, P. \& Bernauer, T. (1995). Towards a new Europe: Stops and starts in regional integration. Westport, CT: Praeger.

Scully, R. (1997). The European parliament and the co-decision procedure: A re-assessment, The Journal of Legislative Studies 3.

Shepsle, K. (1989). Studying institutions: Some lessons from the rational choice approach, Journal of Theoretical Politics 1: 131-147.

Skocpol, T. (1985). Bringing the state back in: Strategies of analysis in current research. In: P. Evans, D. Rueschemeyer \& T. Skocpol (eds.), Bringing the state back in. Cambridge: Cambridge University Press.

Snidal, D. (1986). The game THEORY of international politics. In: K.A. Oye (ed.), Cooperation under anarchy. Princeton: Princeton University Press.

Steunenberg, B. (1994). Decision making under different institutional arrangements: Legislation by the European community, Journal of Institutional and Theoretical Economics 150: $642-669$.

Steunenberg, B., Koboldt, C. \& Schmidtchen, D. (1996). Comitology and the balance of power in the European Union: A game theoretic approach, International Review of Law and Economics 16: 329-344. 
Steunenberg, B., Koboldt, C. \& Schmidtchen, D. (1997). The comitology game: European policy making with parliamentary involvement. In: P. Moser, G. Schneider \& G. Kirchgässner (eds.), Decision rules in the European Union: A rational choice perspective. London: Macmillan (also published as a special issue of Aussenwirtschaft 52: I-II).

Steunenberg, B. (1998). Constitutional change in the European Union: Parliament's impact on the reform of the co-decision procedure. Unpublished Manuscript, University of Twente.

Steunenberg, B. Schmidtchen, D. \& Koboldt, C. (1999). Strategic power in the European Union: Evaluating the distribution of power in policy games. Journal of Theoretical Politics (forthcoming).

Streek, W. (1997). German capitalism: Does it exist? Can it survive? In: C. Crouch \& W. Streek (eds.), Political economy of modern capitalism. London: Sage.

Thelen, K. \& Steinmo, S. (1992). Historical institutionalism in comparative politics. In: S. Steinmo, K. Thelen \& F. Longstreth (eds.), Structuring politics. Historical institutionalism in comparative analysis. Cambridge: Cambridge University Press.

Tsebelis, G. (1994/1995). The power of the European parliament as a conditional agenda setters. American Political Science Review. (Unabridged version in G. Schneider, P. Weitsman \& T. Bernauer (eds.), Towards a new Europe: Stops and starts in regional integration. Westport, CT: Praeger.)

Tsebelis, G. (1997). Maastricht and the democratic deficit. In: P. Moser, G. Schneider \& G. Kirchgässner. (eds.), Decision rules in the European Union: A rational choice perspective. London: Macmillan (also published as a special issue of Aussenwirtschaft 52: I-II).

Tsebelis, G. \& Garrett, G. (1997). Agenda setting, vetoes and the European Union's co-decision procedure, The Journal of Legislative Studies 3.

Tsebelis, George \& Garrett, Geoffrey (2000). Legislative procedures in the European Union, European Union Politics I(1) (forthcoming).

Weibull, J. (1995). Evolutionary game theory. Cambridge, MA: MIT Press.

Wendt, A. (1992). Anarchy is what states make of it: The social construction of power politics, International Organization 46: 391-425.

Wendt, A. (1994). Collective identity formation and the international state, American Political Science Review 88: 384-396.

Wiener, A. (1998). 'European' citizenship practice: Building institutions of a non-state. Boulder, CO: Westview Press).

Williamson, O. (1985) The economic institutions of capitalism. New York: The Free Press.

Wind, M. (1997). Rediscovering institutions: A reflectivist critique of rational institutionalism, in K. E. Joergensen (ed), Reflective approaches to European governance (pp. 15-35). London: Macmillan.

Zetterholm, S. (ed.) (1994). National cultures and European integration: Exploratory essays on cultural diversity and common policies. Oxford: Berg.

Zucker, L. (1991). The role of institutionalization in cultural persistence. In: W. Powell \& P. DiMaggio (eds.), The new institutionalism in organizational analysis. Chicago: University of Chicago Press.

Address for correspondence: Dr. Mark D. Aspinwall, Department of Politics, University of Durham, Durham DH1 3LZ, United Kingdom

Phone: +44 191 374-2810; Fax: +44 199 374-7630; E-mail: m.d.aspinwall@durham.ac.uk 